\title{
Design and Analysis of Various Solar Cell Technologies for Improvements in Efficiencies: A Review
}

Divya Sharma ( $\nabla$ divya13jan@gmail.com )

National Institute of Technical Teachers' Training and Research Chandigarh

Rajesh Mehra

National Institute of Technical Teachers' Training and Research Chandigarh

\section{Balwinder Raj}

National Institute of Technical Teachers' Training and Research Chandigarh

\section{Research Article}

Keywords: Current photovoltaic technologies, efficiency, solar cells, thin film solar cells, wafer silicon based solar cells

Posted Date: May 6th, 2021

DOI: https://doi.org/10.21203/rs.3.rs-469458/v1

License: (c) (i) This work is licensed under a Creative Commons Attribution 4.0 International License. Read Full License 


\section{Abstract}

Solar energy is an inexhaustible source of energy existing on earth. Sun annually delivers approximately 10,000 times of energy that human race currently exploits. Being neat and clean, solar energy has steered path to redeem utilization of conventional resources of energy by birth of solar cells. Solar cells, modules and Photovoltaic systems have been industrialized substantially since race to conquer outer space started during 1960s. Further, oil crisis in 1970s forced the nations to embrace solar technologies as alternative means for conventional sources of energy. Developments in cost efficacy, compact constructions, consistency and lifetime enabled photovoltaics to be the first option for extensive range of uses in day to day life. Photovoltaics are widely used in telecommunications, remote power and cathodic protection. Objective of this paper is to review developments of solar cells since its origin, with comprehensive description of manufacturing processes, implementations and power conversion efficiencies of solar cells of various generations including their future trends and aspects.

\section{Introduction}

Photovoltaic is essentially an intensive technological approach to transform sunlight into electrical energy. Electricity, being the direct current, may be used as alternating current by converting it and can be stored for further exploitation. Hypothetically, a photovoltaic cell is a device that only ingests sunlight and yields electricity. Absence of moving parts, at least not in the atomic way; makes its operation appropriate for the environment. Photovoltaic devices, being eco-friendly and non-toxic, are beneficial and suitable for inhabitants of earth. Photovoltaic systems being flexible by design, their power output may be engineered for almost every application i.e. from low powered consumer uses e.g. wrist-watches, toys calculators and battery chargers to high power consumer uses e.g. solar panels of space satellites [1].

The vital parameters required to examine the capability of a solar cell are short-circuit current density $\left(J_{S C}\right)$, fill factor $(F F)$, open-circuit voltage $\left(V_{O C}\right)$ \& power conversion efficiency (PCE). Figure 1 illustrates $\mathrm{J}_{\mathrm{SC}} \mathrm{V}$ aspects of a solar cell in dark and illuminated ambience. Short-circuit current density $\left(\mathrm{J}_{\mathrm{SC}}\right)$ is elaborated as the current generated by a solar cell under illuminated ambience in the absence of any external load. Open circuit voltage $\left(\mathrm{V}_{\mathrm{OC}}\right)$ can be stated as the difference in potential across two terminals of a solar cell under illuminated condition while no current passes across the terminals [2]. In Eq. 1, Fill Factor (FF) can be elaborated as the ratio of maximum power $\left(\mathrm{P}_{\mathrm{Max}}\right)$ generated to the product of shortcircuit current density $\left(\mathrm{J}_{\mathrm{SC}}\right)$ and open-circuit voltage $\left(\mathrm{V}_{\mathrm{OC}}\right)$ i.e.

$\mathrm{FF}=\mathrm{P}_{\mathrm{Max}} /\left\{\left(\mathrm{J}_{\mathrm{SC}}\right) \times\left(\mathrm{V}_{\mathrm{OC}}\right)\right\}(1)$

Power conversion efficiency of a PV cell is calculated as ratio of the maximum power generated by the solar cell and the incident radiant energy.

\section{Technologies Implemented In Solar Cells}


It has been experienced that present solar cells have some disadvantages but these would likely to astound with the advancement of new technologies. Subsequently, the cost of solar cells along with installation will decrease so that these cells will be within the reach of common man. Presently, search for new materials with properties like low specific gravity, malleable, inexpensive and non-toxic are in progress to manufacture cheaper and reliable solar cells which have higher efficiencies.

The journey of manufacturing processes w.r.t solar cells has seen numerous transformations starting from wafer silicon based to new emerging technology of third generation which is illustrated through

Fig. 2 [3]. Developments of next generation solar cells have boosted the efficiencies of these cells. Solar cells have been differentiated into a number of classes as per materials utilized which are elaborated in the succeeding sections.

\subsection{First Generation Solar Cells (Wafer Silicon Based)}

These cells can also be recognized as conventional/ traditional solar cells which are fabricated on thin silicon layers called wafers. These cells are the most geriatric, also involve eminent technology due to its high energy conversion rates. These cells are further classified into-

\subsubsection{Mono-crystalline/Single crystalline silicon solar cell 2.1.2 Polycrystalline/Multi-crystalline silicon solar cell 2.1.1 Mono-crystalline/Single crystalline silicon Solar Cell (mono c-Si)}

As mentioned by its nomenclature, the entire volume of the cell is a single crystal of silicon. The manufacturing of these crystals is done by Czochralski process which is depicted in Fig. 3a [4-5]. This process involves following steps-

1. Melting of highly pure poly silicon.

2. Dipping of minute crystals deposited over a rod into the molten silicon.

3. Simultaneously pulling and rotation of the rod upwards.

4. Removal of a single, large crystalline ingot. (It involves adjustment in temperature, crystal pulling rate and rpm)

Post formation of silicon ingots, thin wafers of about $0.2-0.8 \mathrm{~mm}$ thick are cut from these ingots which further gets polished to a very high flat surface. The whole process requires a precise processing. Further, thin wafers are recrystallized with fusible metal tin (Sn) by the process of recrystallization. Since formation of mono-crystalline silicon solar cells involves multiple processes, the cells are costly. These cells are chemically stable, have negligible defects. Initially, the power conversion rates of these cells were found to be $17 \%-18 \%$ [3] which further enhanced up to $27.6 \%$ [6]. Crystal structure of silicon in 2D and 3D is illustrated in Fig. 3b and Fig. 3c respectively [7]. 
Major drawback of these cells is that these cells do not operate efficiently whenever the ambient temperature rises above $25^{\circ} \mathrm{C}$. Therefore, an effective air circulation system surrounding the panel must be installed for heat exchanging to avoid unnecessary heating. Subsequently, the efficiency of these cells is also increased [8].

\subsubsection{Polycrystalline/ Multi-crystalline Silicon Solar Cell (Poly-Si or Mc-Si)}

Poly/ Multi-crystalline silicon solar cell is usually manufactured by heating trichlorosilane sedimentation over the silicon rods to maximum temperatures. Distinct crystalline configurations are moulded post molten silicon solidifies $[5,9]$. Polycrystalline silicon solar cells are comparatively inexpensive to fabricate than that of mono-crystalline silicon solar panels because of low processing cost, but the former were comparatively lesser efficient viz $12 \%-14 \%$ [3] which further enhanced up to $23.2 \%$ [6]. Almost $50 \%$ of the total solar cells manufactured worldwide in 2008 were limited to these cells only. Even today, these cells are high in demand among various nations. Ribbon Silicon is very good example of these cells.

\subsection{Second Generation Solar Cells (Thin Film based)}

Synthesis of thin film solar cell involves stacking up of very thin layers of the order of $1 \mu \mathrm{m}$ ( 1 micro meter) of light absorbing materials on a substrates of plastic, glass or metals. Whereas the thickness of silicon wafers is $300 \mu \mathrm{m}$ (micro meter). Therefore, it may be appreciated that thickness of these cells is nearly 300 times thinner than the silicon wafers [3]. In addition to lower thickness, these cells are comparatively flexible and attain lower weight than the conventional first generation cell. For synthesis of thin film solar cell, copper based ternary chalcogenides (here chalcogens refer to elements of group16 in the periodic table) with general formula $\mathrm{Cu}_{\mathrm{a}} \mathrm{BX}$ 估here $\mathrm{B}$ is Tin ( $\left.\mathrm{Sn}\right)$, Antimony (Sb), Bismuth (Bi) and $\mathrm{X}$ is Selenium (Se), Tellurium (Te), Suphur (S) $\}$ is intensely used as $p$-type materials. Copper antimony sulphide $\left(\mathrm{CuSbS}_{2}\right)$ is abundantly available on earth. Subsequently, cost of this sulphate is very low. CuSbS is preferred to $\mathrm{CuInS}_{2}$ as the former occupies direct band gap of $1.5 \mathrm{eV}$ while the latter sustains $1.02 \mathrm{eV}$. Also, for nearly equal ionic radii, Antimony is economical to Indium. Presently, hot injection method is in demand for manufacturing nanoplates and nanoparticles of copper antimony sulphide $\left(\mathrm{CuSbS}_{2}\right)$ with commensurate optical and structural properties. Subsequently, this method resulted in maintaining shape and size uniformity.

Thin film group of solar cells can be listed as mentioned below [10]-

\subsubsection{Amorphous silicon cell (a-Si) \\ 2.2.2 Cadmium Telluride cell (CdTe)}

2.2.3 Copper Indium Gallium Selenium cell (CIGS) 


\subsubsection{Amorphous Silicon Solar Cell (a-Si)}

Amorphous Silicon i.e. a-Si (a non-crystalline structure) solar cells are fabricated by cladding the doped silicon over a flexible or a glass substrate. This is done by highly sophisticated Plasma Enhanced Chemical Vapour Deposition (PECVD) [7]. The visible light incidented on the uppermost layer of a-Si and a part of incidented light lands on the bottom of cell while rest of the light is reflected back. Amorphous Silicon constitutes a band gap of $1.7 \mathrm{eV}$, comparatively greater than that of c-Si. Schematic representation of chemical bonding in a-Si and a-Si: Hydrogen is illustrated in Fig. 4a and Fig. 4b respectively [7]. Schematic stacking of different layers in a typical a-Si cell is illustrated through Fig. 4c [7]. Main demerit of a-Si cells is that their conversion efficiencies are almost unstable fluctuating from 4-8\%. However, these cells can also perform satisfactorily at higher temperatures. Furthermore, these cells are adapted to variable weather conditions where intensity of sunlight is not optimum. The efficiency improvement of a-Si has seen a leap from $2.4 \%$ to $14 \%$ between 1976 and 2020 which is depicted through Table $1[11-14,6]$.

c Schematic arrangement of various films in a typical amorphous Si solar cell.

Table 1

Development of a-Si solar cells \& their conversion efficiencies between 1976-2020

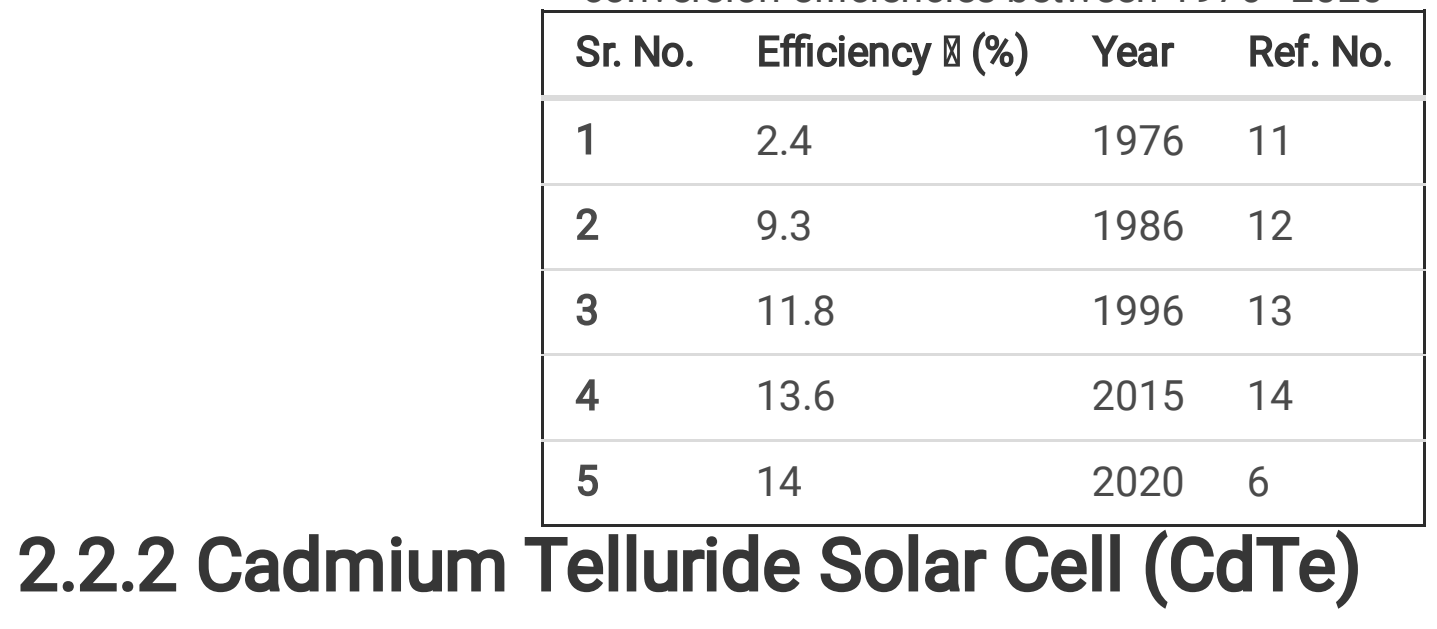

Though Cadmium (Cd) is a highly toxic element and tellurium is available in scarcity yet Cadmium Telluride (CdTe) is a better selection for advancement of low cost photovoltaic device. Its manufacturing technology is inexpensive as well it provides the optimum band gap of approx. $1.45 \mathrm{eV}$ which permits the absorption of light easily, resulting in increased efficiency of solar cell. Since cadmium and tellurium belong to group 12 and group 16 element of the periodic table respectively, these elements possess high optical absorption and chemical stability. Crystal structure (zinc blend cubic) of CdTe solar cell is illustrated in Fig. 5a [7]. Schematic illustration of CdTe solar cell with requisite layers of materials is illustrated in Fig. 5b [7]. Subsequently, these elements are the most appropriate for processing thin film solar cell [15]. The efficiency improvement of CdTe cell has seen a jump from 6\% to $22.1 \%$ between 1972 [16] and 2020 [6].

b Standard Structure of CdTe/CdS Solar Cell. 


\subsubsection{Copper Indium Gallium Di-Selenide Solar Cell (CIGS)}

Copper (Cu), Indium (In), Gallium (Ga) and Selenium (Se) are the main building blocks of CIGS cells which represents the group 11, group 13, group 13 and group 16 respectively of the periodic table. CIGS has general molecular formula of [Culn $\mathrm{Ga}_{1-\mathrm{x}} \mathrm{Se}_{2}$ ]. Copper Indium di Selenide i.e. $\mathrm{x}=1$ was initially developed which had favourable optical and electrical properties with band gap $1.04 \mathrm{eV}$. On further investigation, it was found that its energy level can further be increased to $1.68 \mathrm{eV}$ by replacing indium with gallium [7]. However, only a partial replacement of indium with gallium is done to keep the resistivity of material at optimum level. Therefore, by changing the ratio of quantity of indium to gallium one can tune the forbidden gap between $1.04 \mathrm{eV}-1.68 \mathrm{eV}$ as per requirement. Further, CIGS materials have an optical absorption coefficient of $10^{15}$ per $\mathrm{cm}$ for $1.5 \mathrm{eV}$. Crystal structure of CIGS is illustrated through Fig. 6a [7]. CIGS structure and various layers of described cell is illustrated in the Fig. 6b [8] and Fig. 6c [7] respectively. The efficiency improvement of CIGS cell has seen a jump from $4.5 \%$ to $23.3 \%$ between 1976 [17] and 2020 [6].

c Layer sequence in CIGS Solar Cell.

\subsection{Third Generation Solar Cells (New Emerging Technologies)}

Third Generation also known as multi-junction solar cells improved electrical conductivity while retaining very low manufacturing costs. Recent researches are aiming the efficiencies of $30-60 \%$ with low-priced materials and manufacturing techniques. Types of various third generation cells are as mentioned-

\subsubsection{Organic solar cells (OSC)}

\subsubsection{Quantum dots (QD) solar cells}

2.3.3 Concentrated solar cells (CPV)

\subsubsection{Transparent solar cells (TSC)}

\subsubsection{Perovskite solar cells (PSC)}

\subsubsection{Organic Solar Cells (OSC)}

Organic solar cells comprise of carbon \& hydrogen compounds along with halogens, chalcogens and pnictogens. These cells are manufactured using organic polymers. Organic polymers behave like conductors by displacing $\pi$ electrons and adding of sulphur as doping agent e.g. $\mathrm{P} 3 \mathrm{HT}$ \{poly(3hexylthiophene-2,5-diyl) $\}$ \& PCBM $\{[6,6]$-Phenyl-C61-butyric acid methyl ester $\}$ behaves as donor and acceptor respectively [18]. Architecture and working of various organic solar cells are as follows- 


\section{Architecture and working:}

\section{Single Layer}

The single layer OSC has a single film of photosensitive material. This cell's configuration flops to touch the standard energy efficiencies because of limitations of organic constituents \& demand of energy for splitting of excitons is quite high as depicted in Fig. 7a and 7b [19].

\section{Multiple layer or Hetero-Junction}

Tang, in 1986, observed materials with lower lonization Potential (IP/LUMO) effortlessly provide electrons whereas materials with higher Electron Affinity (EA/HOMO) receive electrons without any difficulty. Subsequently, he discovered a dramatic increase in efficiency introducing a donor \& an acceptor simultaneously in one cell and introduced the first heterojunction photovoltaic cell [19]. In these devices, photocurrent generation process include the following steps-

- Formation of excitons (electron-hole pair) followed by absorption of light packets.

- Diffusion of excitons towards the junction.

- The splitting of excitons into separate holes \& electrons.

- Transportation and accumulation of holes \& electrons at respective electrodes.

Various edifices of heterojunction cells are Bi-layer hetero junction, Bulk Heterojunction (BHJ), Tandem Heterojunction structures.

i. Bilayer or Planar Heterojunction structure- The bilayer heterojunction solar cell also named as planar OSC consists of two closely connected thin films of donor \& acceptor materiel packed between two electrodes as depicted in Fig. 7c [19]. The main drawback of planar OSC is that excitons formed near the junction ( $<\sim 20 \mathrm{~nm}$ ) dissociate only, at larger distances ( $>\sim 20 \mathrm{~nm}$ ) w.r.t junction, the electrons and holes produced is recombined prior reaching donor-acceptor junction because of low mobility and short diffusion length. Consequently, the planar heterojunction fail to achieve higher efficiency.

To ameliorate the proficiency of bilayer organic heterojunction, efforts were made to reduce the film thickness of photosensitive layer to the order of diffusion length of excitons. However, the same were resulted in the formation of ultra-thin film with lower light absorption, subsequently; lesser number of excitons was produced as depicted in Fig. 7d [19].

ii. Bulk or Dispersed Heterojunction (BHJ)- The Bulk Heterojunction (BHJ) solar cell also defined as Dispersed Heterojunction consists of blended donor-acceptor semiconductor materials as shown in Fig. 7e [19]. Consequent to this arrangement, the excitons can easily dissociate into separate electrons \& holes and can be simply diffused to adjoining interface. This configuration has shown much higher PCEs than the Bilayer/ Planar Heterojunctions. Normally, both configurations viz small-molecule based bulk Heterojunction \& polymer based bulk Heterojunction exhibit highest PCEs. In recent time, researchers are more enthusiastic in P3HT:PCBM based BHJ OSC [19]. 
iii. Tandem Heterojunction- As it is well known that light absorption in single layer, planar heterojunction and BHJ OSCs are restricted, Tandem Heterojunction cells can absorb energy packets from the short wavelength zone as well as from the long wavelength zone. Tandem OSCs are well known for its unique feature of maximising the solar spectrum absorption. As depicted in Fig. $7 \mathrm{f}$ and $7 \mathrm{~g}$, Tandem configuration comprises of two BHJ cells with corresponding photo absorption spectrum, parted by an interconnecting layer designed to gather charged particles created within the cells. This interconnecting layer results in the adjustment of the quasi-Fermi levels of the bottom \& the top cell [19].

Due to Van der Waal bonding, an organic tandem solar cell overcomes the problem of photo-voltage loss which occurs because of thermalization of hot charge carriers, produced when photons possessing energy higher than that of band gap are consumed. Consequently, these cells are inexpensive and possess higher efficiency.

Power conversion rate of organic solar cells has been shooted drastically during recent years. Since the materials used in these cells are degradable, these cells enjoy smaller life. Consequently, introduction of these cells in market is a cumbersome job. The progress in energy conversion rate of organic solar cell has been recorded $18.22 \%$ till 2020 [20].

\subsubsection{Nano Crystal based or Quantum dots (QDs) based Solar Cells}

Burnham and Duggan (1990) used Quantum dots (QDs) for the first time in solar cells for ebbing undesirable energy losses with involvement of semiconductors of varying energy levels [21]. QDs are semiconductor nano-particles, usually selected from transition metals of the size of few nanometers equivalent to exciton Bohr radius. Energy levels of QDs can be regulated by altering the dimensions of particles which is not feasible with energy level of same semiconductor of larger size. Subsequently, QDs are undoubtly the favourable candidate for multi-junction solar cells because of its flexibility in tuning of band gaps. Formerly, QDs were manufactured using MCVD technique [21]. Later on, these were prepared by wet chemical processing which was an inexpensive and simpler process. Working procedure of a quantum dot solar cell is described through Fig. 8a [22].

Chuang et al. manufactured single-junction PbS Quantum Dot solar cells. Initially, a glass substrate is layered with ITO. Further, a very thin coating of $\mathrm{ZnO}$ was coated over ITO coated glass substrate using spin coating technique followed by deposition of $\mathrm{PbS}$ Quantum dots coated with oalic acid using solution processing with tetrabutyl-ammonium iodide (TBAI) and 1,2-ethanedithiol (EDT). At last, gold was deposited to the resultant stack as an anode using thermal evaporation technique in vacuum. Photon absorption by quantum dots results in production of free charged particles which gets collected at respective electrodes because of internal electric field generated due to Fermi level orientation of two electrodes. The cell with twelve layers of TBAI processed QDs displayed 6\% energy efficiency. However, substituting the two upper layers of PbS-TbAl with PbS-EDT layers enhanced the energy efficiency to $9 \%$ because these PbS-EDT layers operated as hole transport and $\mathrm{e}^{-}$blocking layer. Interestingly, QDSCs ejects more electrons compared to first generation cells at the cost of each photon. Production of these 
cells is inexpensive comparing to other photovoltaics because these are processed process from solution. The practical energy efficiency of these cells is approximately $2.5 \%$ against hypothetical energy efficiency which is observed to be $45 \%$ [7]. Schematic diagram of QDs solar cell is depicted vide Fig. 8b [22]. The efficiency of QD has been upgraded from 1.46-16.6\% during the period 2009 [23] - 2020 [6].

\subsubsection{Concentrating Solar Cells (CPV)}

Concentrated PV cell is a cell which is illumined by sunlight that usually converged by employing convex lens or concave mirror. The concentration of sunbeam is vital for actualizing solar cells, exhibiting energy conversion efficiencies above 45\%, in particular those aiming at 50\%. Figure 9 depicts the simple arrangement of a concentrator PV cell [24].Concentrated solar cell was first come into light in 70s. This cell functions on the fundamentals of ray optics. It consists of assembly of big converging mirrors and lenses that intend a surge in the power conversion efficiency by converging sunlight that usually fails to fall on the cell surface. Subsequently, a significant amount of thermal energy is generated. In the domain of solar cells, the concentrated solar cell technology has revealed its boosting persona. Based on the arrangement of lenses and mirrors, these cells are categorized into low, medium \& high concentrated PV cells. These cells have exhibited PCE of 38.9 \% [3]. Devoid of moving accessories, swift riposte, low operating charge and performance at atmospheric temperature are significant features of these cells.

\subsubsection{Transparent Solar Cell (TSC)}

Earth receives plenty of sunrays but a large portion of its goes in vain and the balance energy is limited to solar farms and panels of rooftops. Currently, TSCs have attracted the consideration of scientists due to their increased utilization in society. These cells have been commercialized in many countries while some nations are considering for its utilization in forthcoming years post significant enhancement of their efficiency. TSCs exhibit the capability to yield the energy equal to $40 \%$ of energy exploitation of buildings provided the availability of TSCs possessing $90 \%$ of glass over exterior of each structures/ buildings. Notwithstanding, many developed and developing countries including India are utilizing transparent solar cell technology in automobiles and electronic gadgets. Transparent solar cell consists of an ITO or FTO film coated on a glass substrate, having $10 \Omega$ per square resistance along with a layer thickness of approximately $20 \mathrm{~nm}$. In addition to intrinsic optical reductions of glass itself, these films decrease the transparency of cell by $15 \%-20 \%$ prior another layer is piled. Till date nearly $80 \%$ of transparency is attained [25].

Figure 10 Illustrate the compostions of the TSC [25-26]. An ultra-sensitive layer against UV and NIR radiations is sandwiched between both electrodes which are transparent. The cell includes PBDTT-DPP and PCBM as e- donor and e-acceptor respectively, and both are combined to form a proactive PBDTTDPP:PCBM layer. $73 \%$ and $68 \%$ are the maximum and average transmission respectively for the photoactive material w.r.t visible region $(400 \mathrm{~nm}$ to $650 \mathrm{~nm})$. Nonetheless, a UV alongwith NIR region sturdily engrosses light. To modify the cell, the anode substrate, ITO; coated with PEDOT: PSS is positioned as the bottommost layer. Since the organic materials are quite sensitive, the electrode needs to 
be positioned at the topmost though this may not sustain the film sedimentation procedure. To prevail over the scenario, a thin coat of AgNW is layered by spraying technique over the resultant stack. AgNW is stuck to the photosensitive film in existence of $\mathrm{TiO}_{2}$ sol-gel solution. It needs minute processing [26]. The efficiency of TSC cells has been increased from 4-8.02\% within the period from 2012 [26] - 2014 [27]. Scientists are now working towards the boosting of the efficiency of TSC without compromising its transparency; the same will be probably achieved in the forthcoming five years.

\subsubsection{Perovskite Based Solar Cell (PSC)}

LA Perovski, a Russian scientist, discovered Calcium Titanate, $\mathrm{CaTiO}_{3}$, in 1839, having an orthorhombic crystal symmetry in which larger $\mathrm{Ca}^{2+}$ ions were positioned at the corners while smaller sized $\mathrm{Ti}^{4+}$ were positioned at the body cubic centre and $\mathrm{O}^{2-}$ were situated at face centre in the structure hence was named perovskite in honour of the Russian scientist. Post this discovery, materials with chemical composition $\mathrm{CDX}_{3}$ \& crystal structure identical to $\mathrm{CaTiO}_{3}$ are identified as perovskites where $\mathrm{C}, \mathrm{D}$ and $\mathrm{X}$ and analogous to $\mathrm{Ca}^{2+}, \mathrm{Ti}^{4+}$ and $\mathrm{O}^{2-}[7]$.The perovskites exhibit a highly stable three dimensional network structure. Some common perovskites are $\mathrm{CsSnl}_{3}, \mathrm{FAPbl}_{3}, \mathrm{CaTiO}_{3}, \mathrm{MAPb}_{3}, \mathrm{MAPbBr}_{3}$ and $\mathrm{MASnl}_{3}$. The perovskites possess many magnificent properties viz superconductivity, spintronics \& magnetoresistance. Miyasaka et al. were the first to use perovskites as a photoactive material in a DSSC [28]. In 2009, they utilized $\mathrm{MAPbl}_{3}$ \& $\mathrm{MAPbBr}_{3}$ as photoactive materials, mesoporous $\mathrm{TiO}_{2}\left(\mathrm{~m}-\mathrm{TiO}_{2}\right)$ as $\mathrm{ETM}$. $\mathrm{Lil} / \mathrm{I}_{2}$ in $\mathrm{CH}_{3} \mathrm{OCH}_{2} \mathrm{CN}$ and $\mathrm{LiBr} / \mathrm{Br}_{2}$ in $\mathrm{CH}_{3} \mathrm{CN}$ had been taken as electrolytes i.r.o MAPbI \& MAPbBr respectively for two separate DSSCs. However, they exhibited lower efficiencies $3.81 \%$ and $3.13 \%$ respectively. In addition these cells were unstable. In 2012, Gratzel et al. were the first to synthesize $\mathrm{MAPbl}_{3}$ sensitized solar cells using spiroOMeTAD as HTM in solid form [7]. Surprisingly, this cell exhibited the energy efficiency of $9.7 \%$ which provoked the scientists for perovskite materials that led to the rise to unique type of solar cells termed as perovskite solar cells.

The initial perovskite solar cell used FTO shielded with glass substrates. Further, the substrate was deposited with thin film $\mathrm{TiO}_{2}$ using spin coating method followed by annealing at nearly $500^{\circ} \mathrm{C}$ for the duration of 20 minutes. The compact layer developed, acted like ETM and constrained the hole activity. Additionally, it behaved like a barrier between FTO and perovskite layer. Thereafter, a layer of $\mathrm{m}-\mathrm{TiO}_{2}$ was encrusted upon compact deposition of $\mathrm{TiO}_{2}$ through the process of doctor blading, followed by sintering carried out for the duration 45 minutes at $550^{\circ} \mathrm{C}$. After that, the resultant compound was layered by employing $\mathrm{MAPbl}_{3}$, accompanied by heat treatment at $100^{\circ} \mathrm{C}$ for the duration of 10 minutes. Subsequently nanocrystal $\mathrm{MAPbl}_{3}$ developed over $\mathrm{m}-\mathrm{TiO}_{2}$ coating. Further, a film of spiro-OMeTAD was coated onto $\mathrm{MAPbl}_{3}$ using spin coating technique [28]. This film acted as HTL. At last, the cell was accomplished with final sedimentation of thin layer of gold $(\mathrm{Au})$ by employing thermal evaporation process. Crystal and Schematic view of Perovskite cell is depicted in Fig. 11a and Fig. 11b respectively [7].

Gratzel et al. in 2013, elaborated an advance procedure for built-up of perovskite film onto $\mathrm{m}-\mathrm{TiO}_{2}$ layer that gave rise to controlled configuration of perovskite film. Moreover, this resultant perovskite film had the 
ability to be adsorbed deeply in $\mathrm{m}-\mathrm{TiO}_{2}$ film which previsiously was not feasible. As a result, PCE of the cell touched the limit of 15\% [29]. Over the past few years, Yang et al. exalted the efficacy of ETL by addition of yttrium $(Y)$ in the compact $\mathrm{TiO}_{2}$ layer that led to increase in cell efficiency upto19.3\% [30]. Ultimately, the energy efficiency rate of perovskite cells shoot up to $25.2 \%$ from $3.8 \%$ [31] till 2020 as shown in Table $2[32-35,6]$. On the other hand, durability and stability of perovskite cells need notable improvement. Nonetheless, scientists are highly optimistic to fabricate the perovskite cells of higher power efficiencies with very low cost.

Table 2

Progress in perovskite cells w.r.t. efficiencies during 2001-2020

\begin{tabular}{|c|c|c|c|c|c|c|c|}
\hline $\begin{array}{l}\text { Sr. } \\
\text { No. }\end{array}$ & Structure & Voc & $\begin{array}{l}\text { Jsc } \\
(\mathrm{mA} \\
\text { per } \\
\left.\mathrm{cm}^{2}\right)\end{array}$ & $\begin{array}{l}\text { FF } \\
(\%)\end{array}$ & $\begin{array}{l}\text { Efficiency } \\
(\%)\end{array}$ & Year & $\begin{array}{l}\text { Ref. } \\
\text { No. }\end{array}$ \\
\hline 1 & $\begin{array}{l}\text { CulnS }_{2}(\mathrm{HTL}) / \mathrm{MAPbl}_{3}(\mathrm{PA}) / \\
\mathrm{TiO}_{2}(\mathrm{ETL}) / \mathrm{FTO}\end{array}$ & 0.881 & 23.26 & 81.57 & 16.72 & 2001 & 32 \\
\hline 2 & $\begin{array}{l}\mathrm{MAPbl}_{3} \text { perovskite sensitizer on } \\
\mathrm{TiO}_{2}\end{array}$ & 0.61 & 11 & 57 & 3.81 & 2009 & 31 \\
\hline 3 & $\begin{array}{l}\text { Glass/FTO }\left(\mathrm{SnO}_{2}: \mathrm{F}\right) / \mathrm{N} \text {-type } \\
\mathrm{PCBM}(\mathrm{ETL}) / \\
\mathrm{MAPbI}_{3} / \mathrm{PEDOT}: \mathrm{PSS}(\mathrm{HTL}) / \mathrm{Ag}(\text { Back } \\
\text { contact) }\end{array}$ & 1.52 & 25.60 & 81.58 & 31.77 & 2017 & 33 \\
\hline 4 & $\begin{array}{l}\text { Glass/TCO/ZnSe (ETL) /IDL/ } \\
\mathrm{MAPbl}_{3} / \mathrm{IDL} / \mathrm{Cul}(\mathrm{HTL}) / \text { Metal } \\
\text { contact }\end{array}$ & 1.2439 & 23.778 & 87.96 & 26.11 & 2018 & 34 \\
\hline 5 & - & - & - & - & 25.2 & 2020 & 6 \\
\hline
\end{tabular}

\section{Conclusion}

As described in the preceding paragraphs, it has been concluded that recognition of solar cells depend on cost-efficacy, lifespan and efficiency. First generation solar cells are undoubtedly the first choice of consumers due to their low cost and best available efficiency of $27.6 \%$ in spite of various researches on advanced solar cells of second generation and third generation. Further, cells of second generation are also promising due to their low cost. In addition, synthesis of these cells is inexpensive than the first generation cells. However, availability of raw material is an issue and lots of efforts are required to improve their efficiencies which are maximum $23.3 \%$ till date. It can be seen that while moving from first generation to second generation efficiency of solar cell have decreased by $4.3 \%$. Solar cells of third generation are the most advanced devices. Raw materials used in first generation are monocrystalline and polycrystalline Silicon. The materials utilized for second generation cells are CdTe and CIGS. While shifting to third generation of solar cells organic materials, perovskites and nano-sized Quantum Dots are 
used. Subsequently, efficiency of solar cell has been increased by $11.3 \%$ while switching from first generation of solar cells to third generation. Commercialization of cells of third generation is miles away due to degradation of the material in short span. However, scientists are putting their best efforts for exploring advance techniques to eradicate the deficiency pertaining to commercialization of third generation solar cells.

\section{Declarations}

\section{Funding statement:}

The authors declare that they have no funding available for the publication chargers of open access. Consider the paper as regular paper.

\section{Conflict of Interest:}

Authors declare that there is no conflict of Interest.

\section{Availability of data and material:}

Data used for the results are available in the manuscript in tabular and graphical form.

\section{Compliance with ethical standards:}

Not applicable

\section{Consent to participate:}

We here give our consent to participate and communicate paper in this journal.

\section{Consent for Publication:}

We here give our consent to publish paper in the journal of Silicon, Springer.

\section{Acknowledgment}

Research Scholar is thankful to faculty of CDC Department, Department of Electronics and Communication Engineering NITTTR Chandigarh for their interest in this work and useful comments to draft the final form of the paper. We would like to thank NITTTR Chandigarh for lab facilities and research environment to carry out this work.

\section{References}

[1] Rathore, N., Panwar, N.L., Yettou, F., \& Gama, A. 2019. A Comprehensive review on different types of solar photovoltaic cells and their applications. International J. of Ambient Energy: 1-50, 
[2] Solar Cell: Working Principle \& Construction. Source: Electrical4U, Oct. 28, 2020, https://www.electrical4u.com/solar-cell.

[3] Sharma, S., Jain, K.K., \& Sharma, A.2015.Solar Cells: In Research and Applications-A Review. Mater. Sci. and Appl. 6: 1145-1155, https://doi.org/10.4236/msa.2015.612113

[4] Czochralski-process, http://www.top.alternate-energy-sources.com/Czochralski-process.html

[5] Jiang, L., Cui, S., Sun, P., Wang, Y., \& Yang, C. 2020. Comparison of Monocrystalline and Polycrystalline Solar Modules. Proceedings of 5th IEEE Information Technology and Mechatronics Engineering Conference: 341- 344, https://doi.org/10.1109/ITOEC49072.2020.9141722

[6] National Renewable Energy Laboratory, Best research-cell efficiencies. https://www.nrel.gov/pv/assets/images/best-research-cell-efficiencies.20200406.

[7] Kumar, P., 2017. Handbook of Organic Solar Cells- Device Physics. Processing, Degradation, and Prevention, CRC Press, Taylor \& Francis Group, New York. Pp. 1-136, http://lccn.loc.gov/2016008260

[8] Eldin, A.H., Refaey, M., \& Farghly, A. 2015. A Review on Photovoltaic Solar Energy Technology and its efficiency. Proceedings of 17th International Middle-East Power Sys. Conference (Egypt): 1-8, https://www.academia.edu/15643835

[9] Fujiwara, K., Pan, W., Usami, N., Sawada, K., Tokairin, M., Nose, Y., Nomura, A., Shishido, T., \& Nakajima, K. 2016. Growth of structure-controlled polycrystalline silicon ingots for solar cells by casting. Acta Materialia. 54(12): 3191-3197, https://doi.org/10.1016/j.actamat.2006.03.014

[10] Lee, T.D., \& Ebong, A.U. 2017. A review of thin film solar cell technologies and challenges. Ren. and Sus. Energy Reviews. 70: 1286-1297, https://doi.org/10.1016/j.rser.2016.12.028

[11] Carlson, D.E., \& Wronski, C.R. 1976. Amorphous silicon solar cell. Appl. Phys. Lett. 28(11): 671- 673, https://doi.org/10.1063/1.88617

[12] Yamazaki, S., Abe, M., Nagayama, S., Shibata, K., Susukida, M., Fukada, T., Kinka, M., Kobayashi, I., Inushima, T., \& Suzuki, K. 1986. Fabrication of the Large-Area Integrated a-Si Solar Cells. MRS Proceedings. Cambridge University Press. 70: 487-492, https://doi.org/10.1557/PROC-70-487

[13] Yang, J., Xu, X., Banerjee, A., \& Guha, S. 1996. Proceedings of 25th IEEE PVSC. 1041.

[14] Sai, H., Matsui, T., Koida, T., Matsubara, K., Konda, M., Sugiyama, S., Katayama, H., Takeuchi, Y., \& Yoshida, I. 2015. Triple-junction thin-film silicon solar cell fabricated on periodically textured substrate with a stabilized efficiency of 13.6\%. Appl. Phys. Lett. 106(21): 213902, https://doi.org/10.1063/1.4921794 
[15] Bosio, A., Rosa, G., \& Romeo, N. 2018. Past, present and future of the thin film CdTe/CdS solar cells. Solar Energy. 175: 31-43, https://doi.org/10.1016/j.solener.2018.01.018

[16] Bonnet, D., \& Rabenhorst, H. 1972. New results on the development of a thin-film p-CdTe-n-CdS heterojunction solar cell. Proceedings of $9^{\text {th }}$ IEEE Photovoltaic Specialists Conference: 129-131.

[17] Kazmerski, L.L., White, F.R., \& Morgan, G.K. 1976. Thin-film CulnSe2/CdS heterojunction solar cells. Applied Phys. Lett. 29(4): 268-270, https://doi.org/10.1063/1.89041

[18] Sharma, D., Mehra, R., \& Raj B. 2021. Comparative Analysis of Photovoltaic Technologies for High Efficiency Solar Cell Design. Superlattices and Microstructures. 153: 106861, https://doi.org/10.1016/j.spmi.2021.106861

[19] Khalil, A., Ahmed, Z., Touati, F., \& Masmoudi, M. 2016. Review on organic solar cells. 13th International Multi-Conf. on Sys., Signals \& Devices (SSD): 342-353, https://doi.org/10.1109/SSD.2016.7473760

[20] Liu, Q., Jiang, Y., Jin, K., Qin, J., Xu, J., Li, W., Xiong, J., Liu, J., Xiao, Z., Sun, K., Yang, S., Zhang, X., Ding, L. 2020. 18\% efficiency organic solar cells. Sci. Bull. 65(4): 272-275, https://doi.org/10.1016/j.scib.2020.01.001

[21] Barnham, K.W.J., \& Duggan, G. 1990. A new approach to high-efficiency multi-band-gap solar cells. J. of App. Phys. 67(7): 3490-3493, https://doi.org/10.1063/1.345339

[22] Baker, D.R., \& Kamat, P.V. 2009. Photosensitization of $\mathrm{TiO}_{2}$ nanotubes with CdS quantum dots: Particulate versus tubular support architectures. Adv. Funct. Mater. 19: 805-811, https://doi.org/10.1002/adfm.200801173

[23] Lee, H., Leventis, H.C., Moon, S.J., Chen, P., Ito, S., Haque, S.A., Torres, T., Nuesch, F., Geiger, T., Zakeeruddin, S.M., Graetzel, M., \& Nazeeruddin, M.K. 2009. PbS and CdSquantum dot-sensitized solidstate solar cells: old concepts, new results. Adv. Funct. Mater. 19(17): 2735-2742, https://doi.org/10.1002/adfm.200900081

[24] High efficiency concentrated photovoltaic system, http://www.oejournal.org/item/news2020006.html [25] Husain, A.A.F., Hasan, W.Z.W., Shafie, S., Hamidon, M.N., \& Pandey, S.S. 2018. A review of transparent solar photovoltaic technologies. Renew. Sustain. Energy Rev. 94: 779-791, https://doi.org/10.1016/j.rser.2018.06.031

[26] Chen, C.C., Dou, L., Zhu, R., Chung, C.H., Song, T.B., Zheng, Y.B., Hawks, S., Li, G., Weiss, P.S., \& Yang, Y. 2012. Visibly transparent polymer solar cells produced by solutionprocessing, ACS Nano. 6(8): 7185-7190, https://doi.org/10.1021/nn3029327

[27] Yusoff, A.R.b.M., Lee, S.J., Shneider, F.K., Silva, W.J.d., \& Jang, J. 2014. High-performance semitransparent tandem solar cell of $8.02 \%$ conversion efficiency withsolution-processed graphene mesh and 
laminated Ag nanowire top electrodes. Adv. Energy Mater. 4(12): 1301989, https://doi.org/10.1002/aenm.201301989

[28] Sharma, D., Mehra, R., \& Raj, B. 2020. Recent Advances in Power Systems. In: Gupta, O.H. (Ed.). Materials and Methods for Performance Enhancement of Perovskite Photovoltaic Solar Cells: A Review, EPREC. 699. Pp. 531-542, Springer Nature, Singapore Pte Ltd. https://doi.org/10.1007/978-981-15-79943_49

[29] Burschka, J., Pellet, N., Moon, S.J., Baker, R.H., Gao, P., Nazeeruddin, M.K., \& Gratzel, M.2013. Sequential deposition as a route to high-performance perovskite-sensitized solar cells. Nature. 499(316): 316-320, https://doi.org/10.1038/nature12340

[30] Zhou, H., Chen, Q., Li, G., Luo, S., Song, T.b., Duan, H.S., Hong, Z., You, J., Liu, Y., \& Yang, Y. 2014. Interface engineering of highly efficient perovskite solar cells. Sci. 345(6196): 542-546, https://doi.org/10.1126/science. 1254050

[31] Kojima, A., Teshima, K., Shirai, Y., \& Miyasaka, T. 2009. Organometal halide perovskites as visible-light sensitizers for photovoltaic cells. J. Am. Chem. Soc. 131(17): 6050-6051, https://doi.org/10.1021/ja809598r

[32] Henderson, D.O., Mu, R., Ueda, A., Wu, M.H., Gordon, E.M., Tung, Y.S., Huang, M., Keay, J., Feldman, L.C., Hollingsworth, J.A., Buhro, W.E., Harris, J.D., Hepp, A.F., \& Raffaelle, R.P. 2001. Optical and structuralcharacterization of copper indium disulfide thin films. Mater. Des. 22(7): 585-589, https://doi.org/10.1016/S0261-3069(01)00019-X

[33] Mandadapu, U., Vedanayakam, S.V., \& Thyagarajan, K. 2017. Simulation and Analysis of Lead based Perovskite Solar Cell using SCAPS-1D. Indian J. of Sci. and Tech. 10(11): 1-8, https://doi.org/10.17485/ijst/2017/v11i10/110721

[34] Salah, M.M., Hassan, K.M., Abouelatta, M., \& Shaker, A. 2018. A Comparative Study of Different ETMs in Perovskite Solar Cell with Inorganic Copper lodide as HTM. Optik. 178: 958-963, https://doi.org/10.1016/j.jileo.2018.10.052

[35] Kaur, P., Pandey, V., \& Raj, B. 2020. Comparative Study of Efficient Design, Control and Monitoring of Solar Power using loT. Sensor Letter. 18(5): 419-426, https://doi.org/10.1166/sl.2020.4225

\section{Figures}




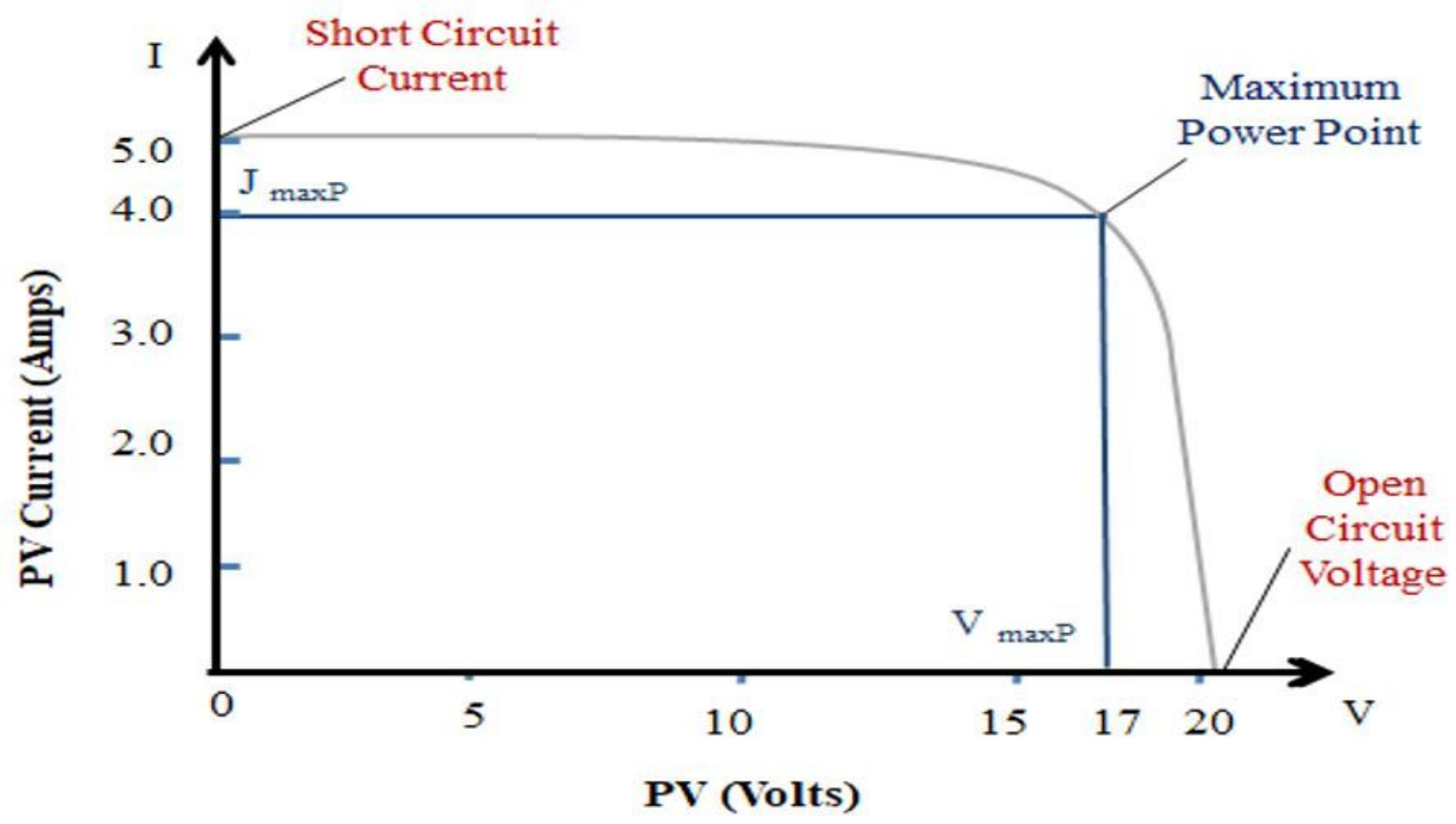

Figure 1

Voltage / Current Characteristics.

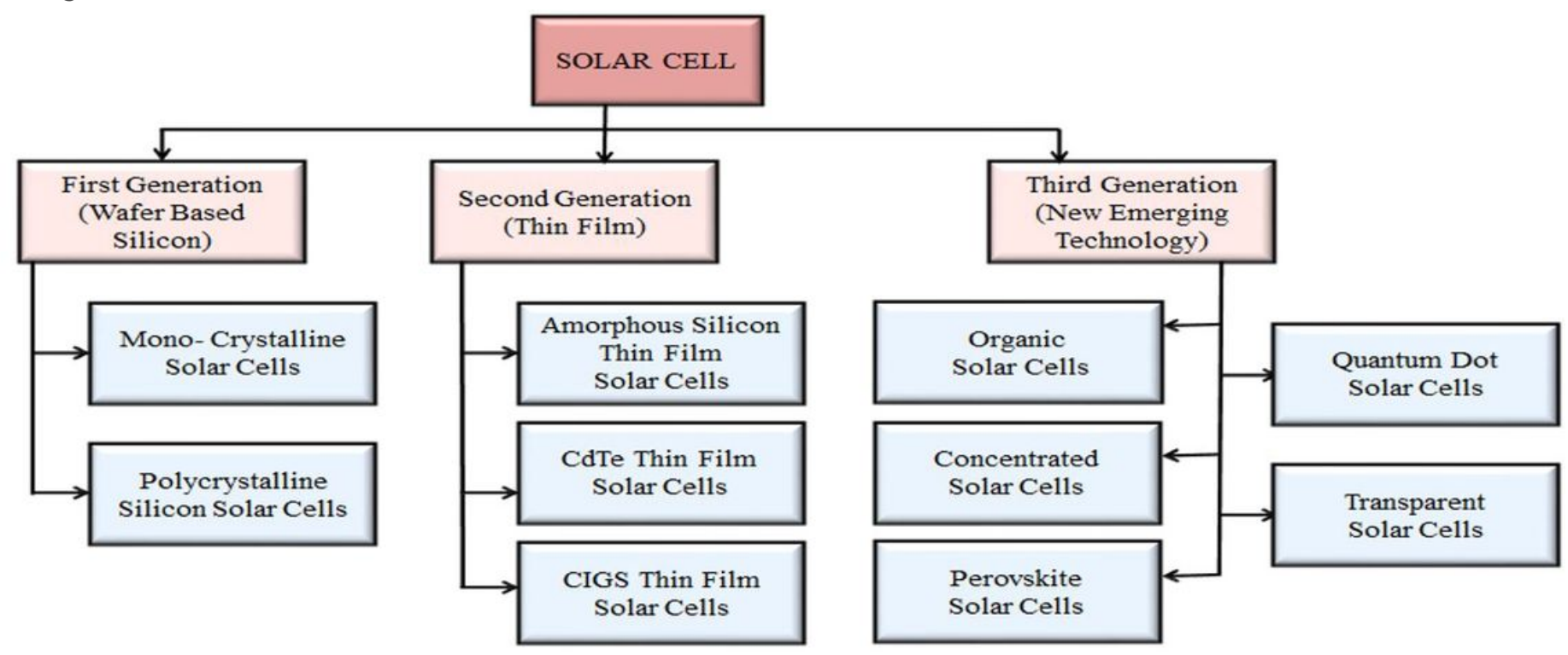

Figure 2

Various solar cell technologies and trending developments. 
a

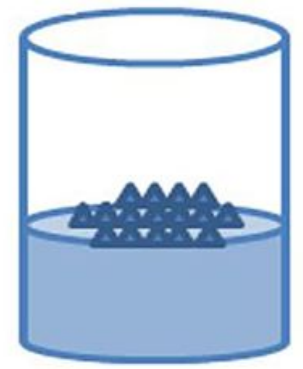

Melting of poly-silicon, doping

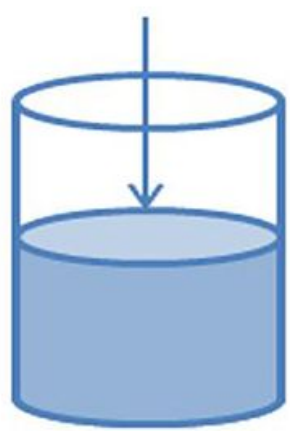

Introduction of the seed crystal

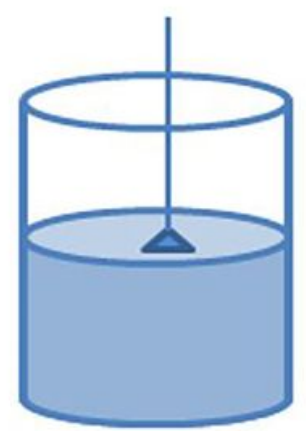

Beginning of the crystal growth

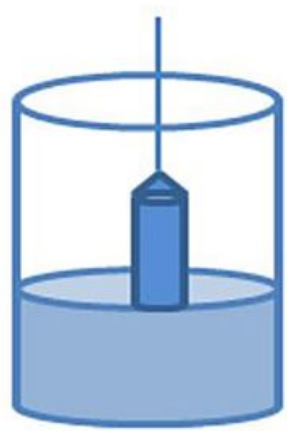

Crystal pulling

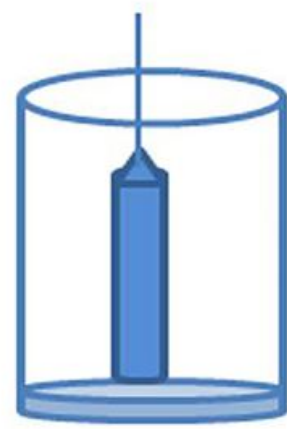

Formed crystal with a residue of melted silicon
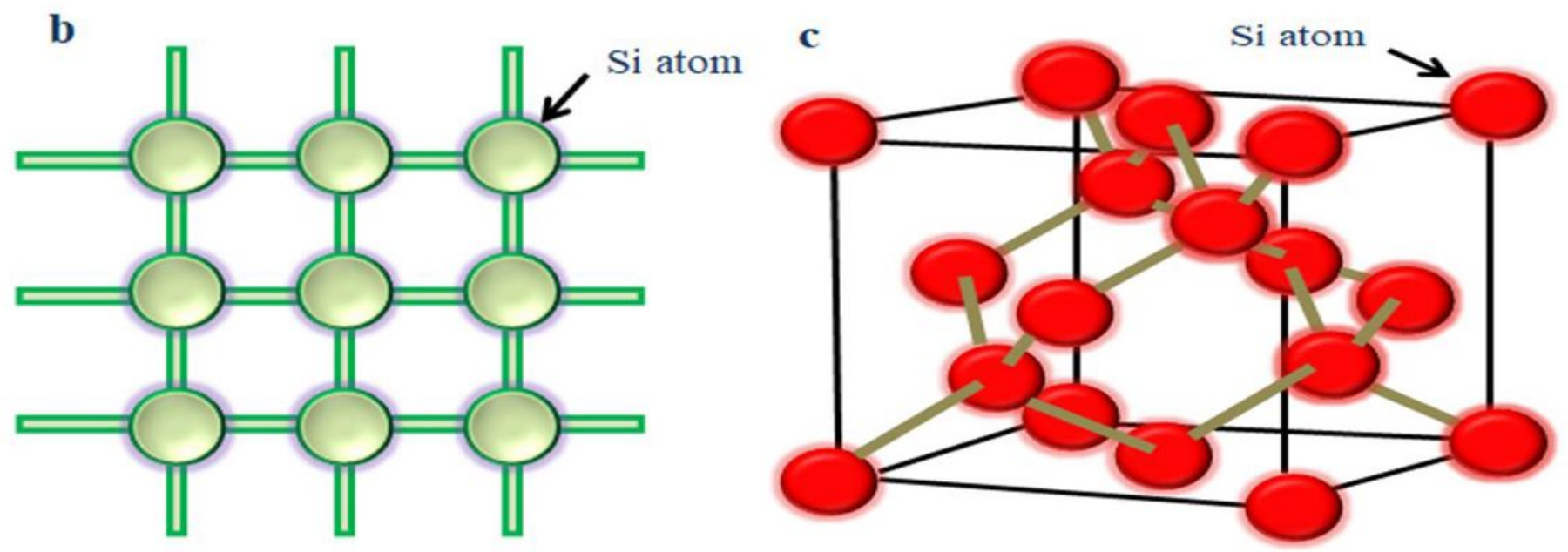

Figure 3

a Czochralski Process; b Crystal Structure of Si in 2-D; and c Crystal Structure of Si in 3-D. 
a

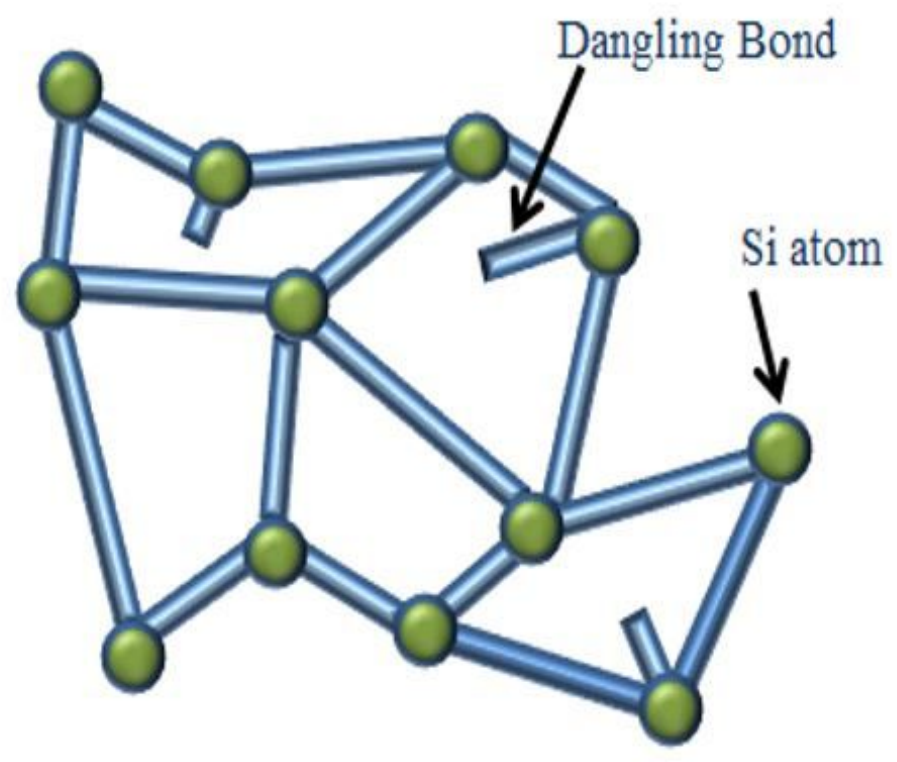

b

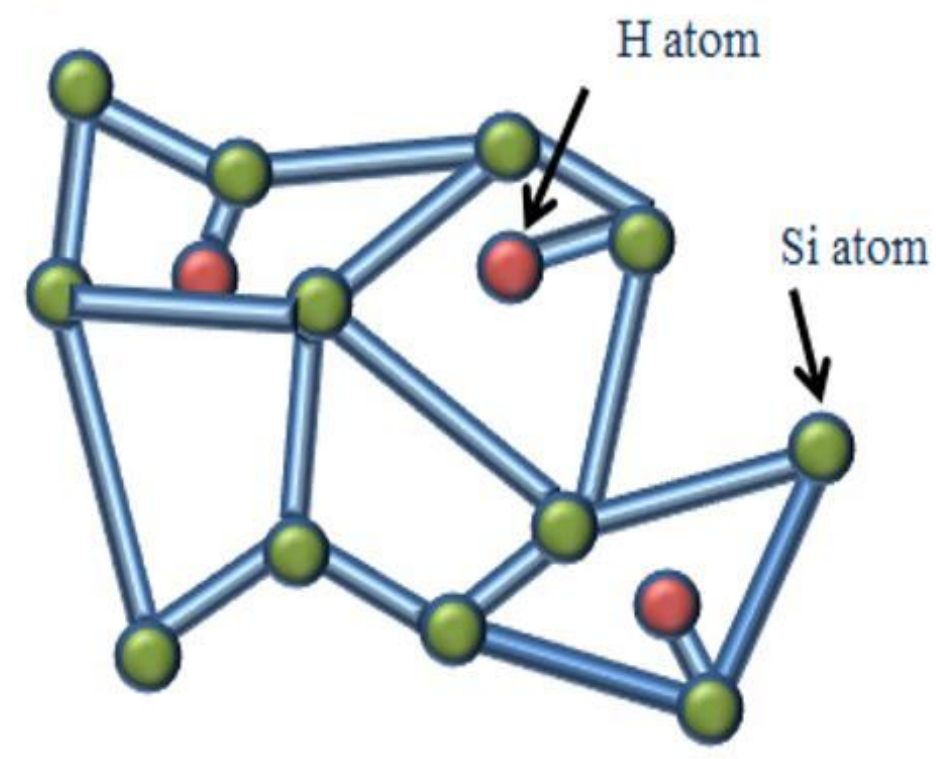

c

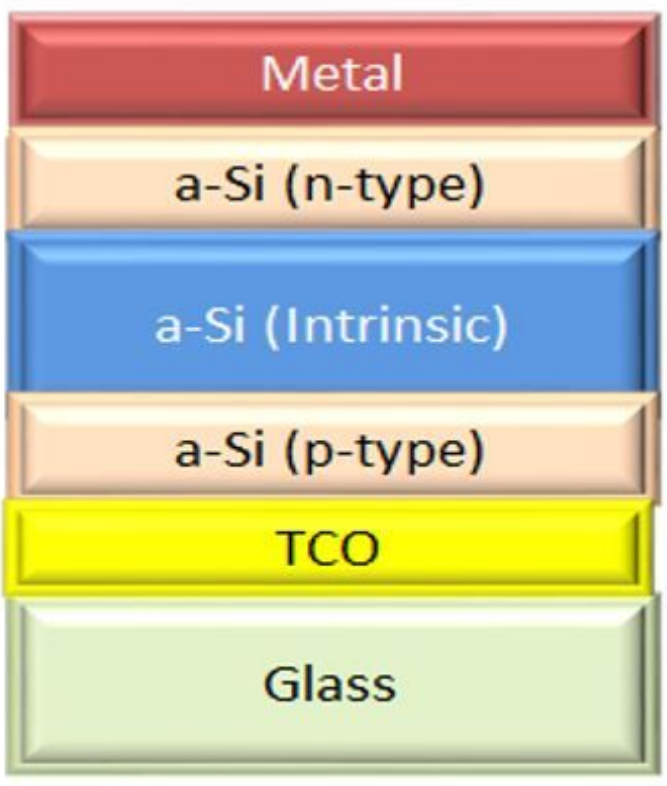

Figure 4

Schematic representation of chemical bonding in a a-Si and b a-Si:H; and c Schematic arrangement of various films in a typical amorphous Si solar cell. 

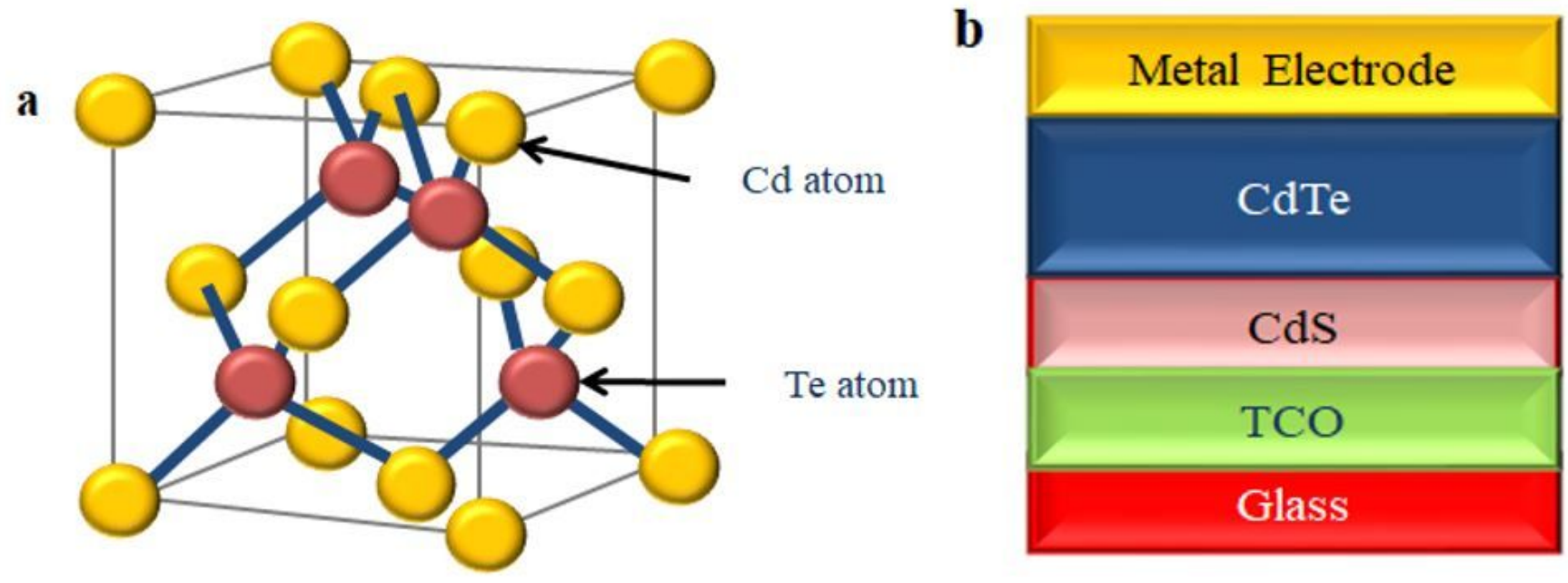

\section{Figure 5}

a Crystal structure (zinc blend cubic) of CdTe; and b Standard Structure of CdTe/CdS Solar Cell.

a

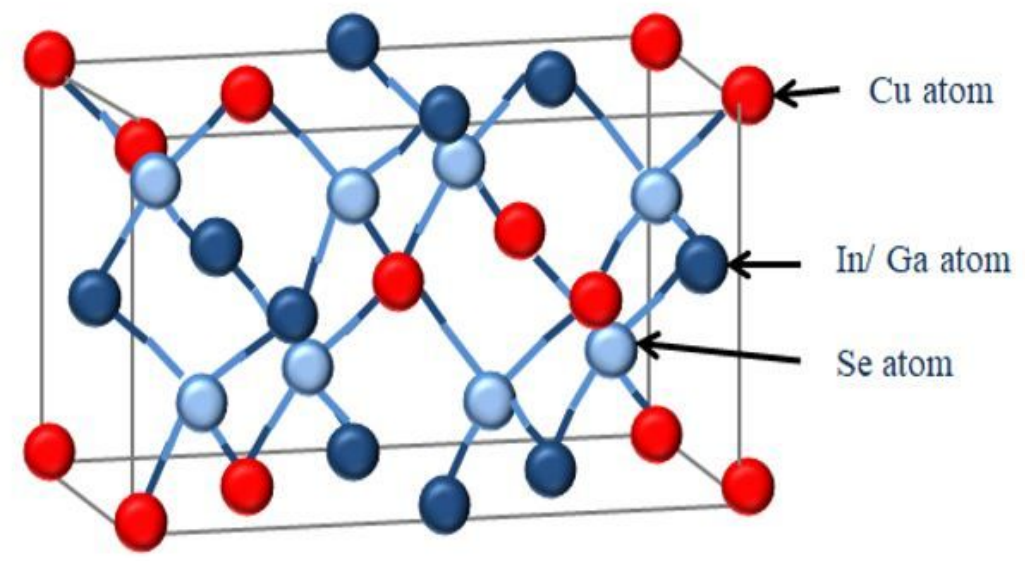

b

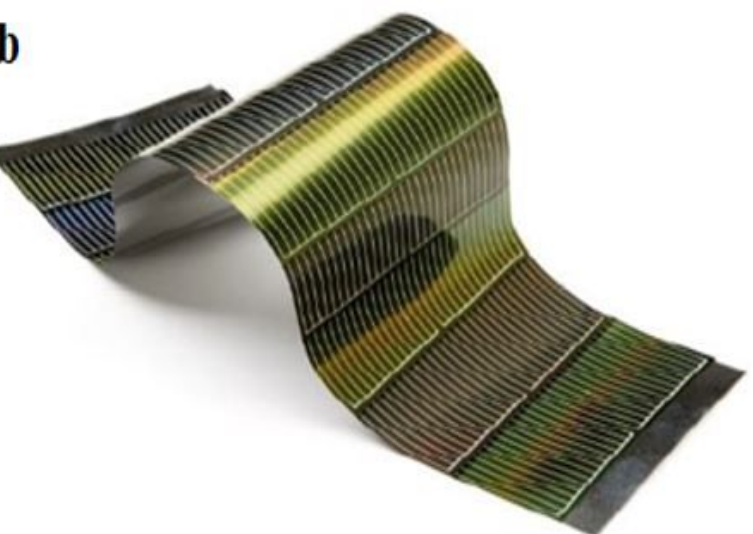

$\mathbf{c}$

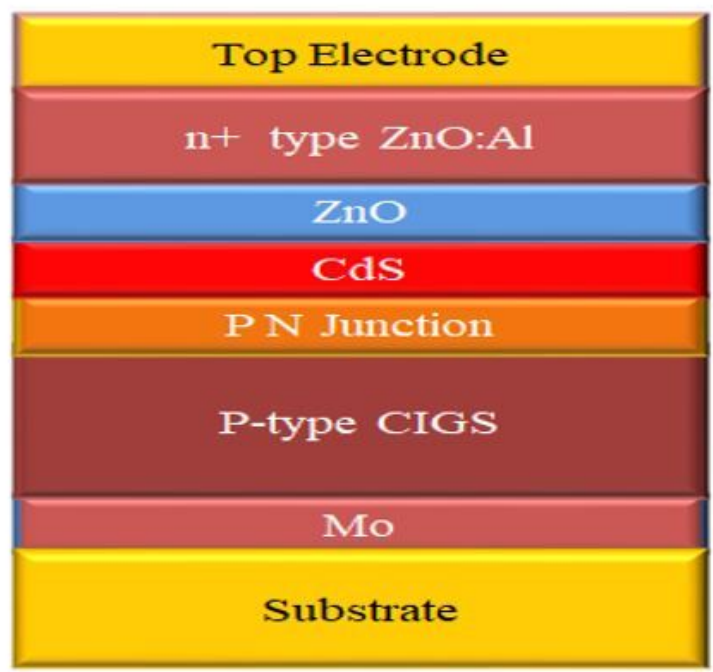

Figure 6 
a Crystal structure of CIGS chalcopyrite; b CIGS Solar Cell [8]; and c Layer sequence in CIGS Solar Cell.
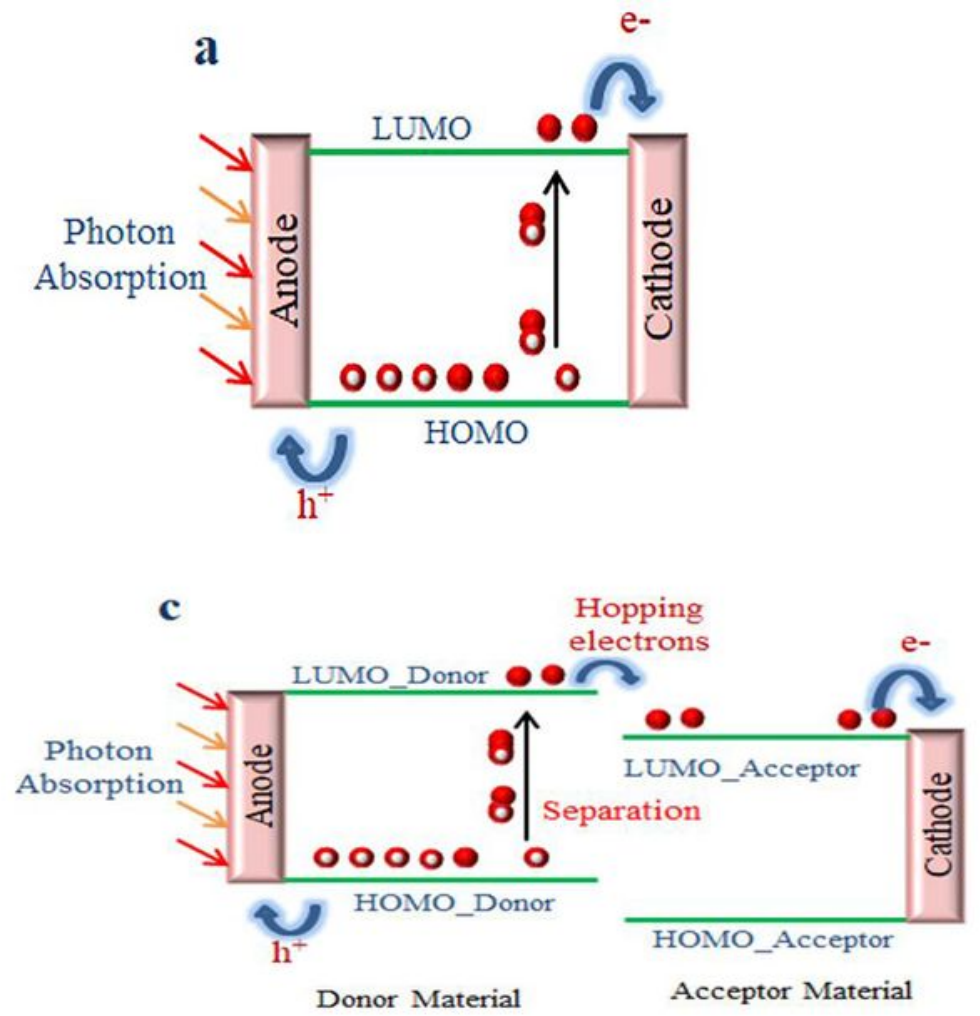

b

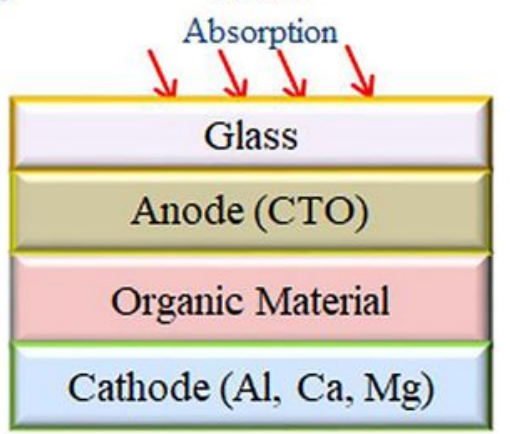

d

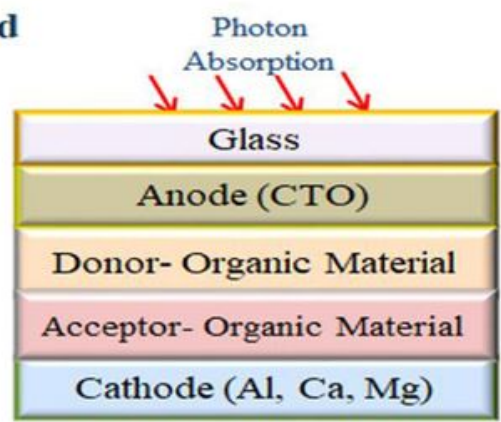

e

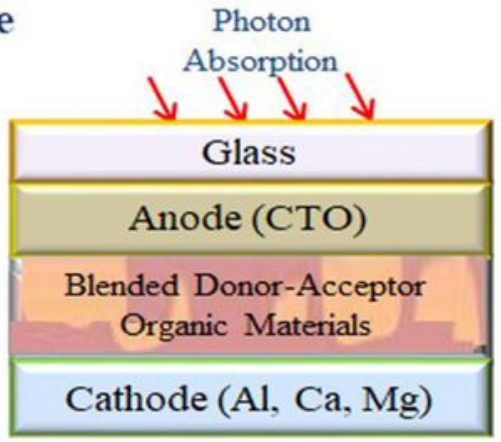

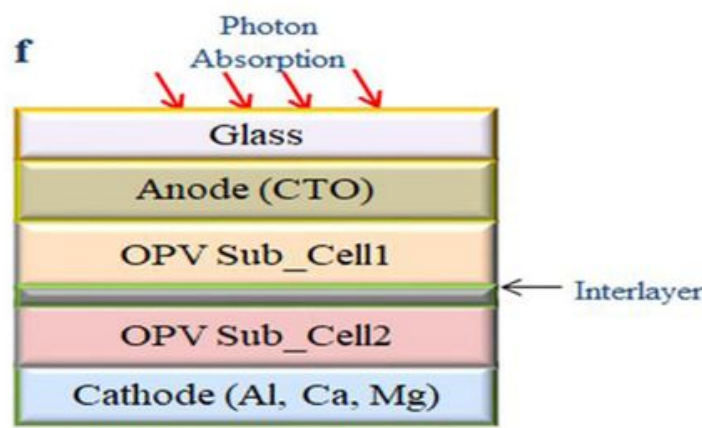

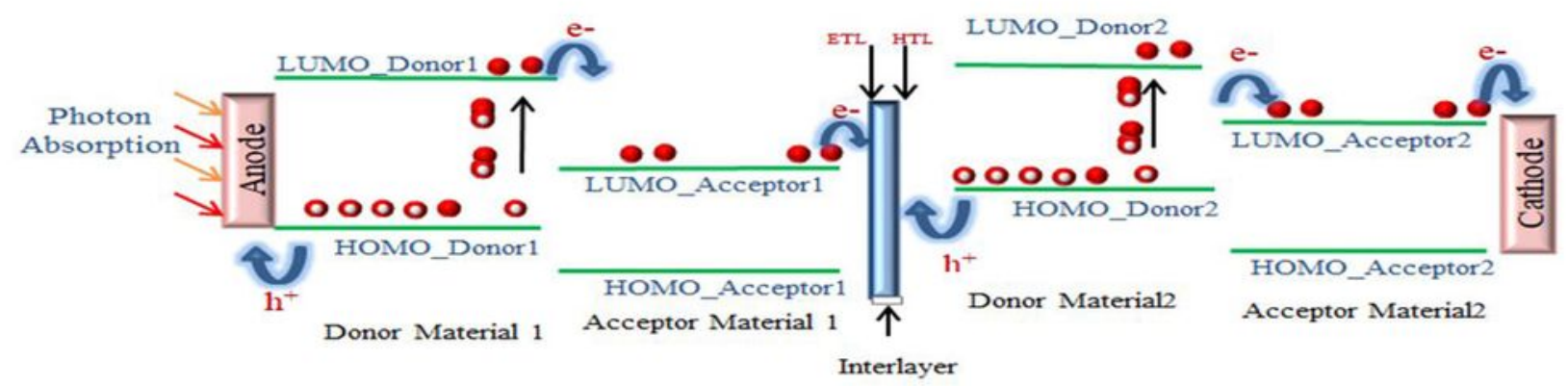

Figure 7

a Simplified Energy Diagram of a single Layer OSC \& b Single layer OSC. c Simplified Energy Diagram of a Bilayer Heterojunction Solar Cell; and d Bilayer Heterojunction Solar Cell. e Bulk Heterojunction; and $f$ Tandem Heterojunction Solar Cell. g Simplified Energy Diagram of a Tandem OSC. 

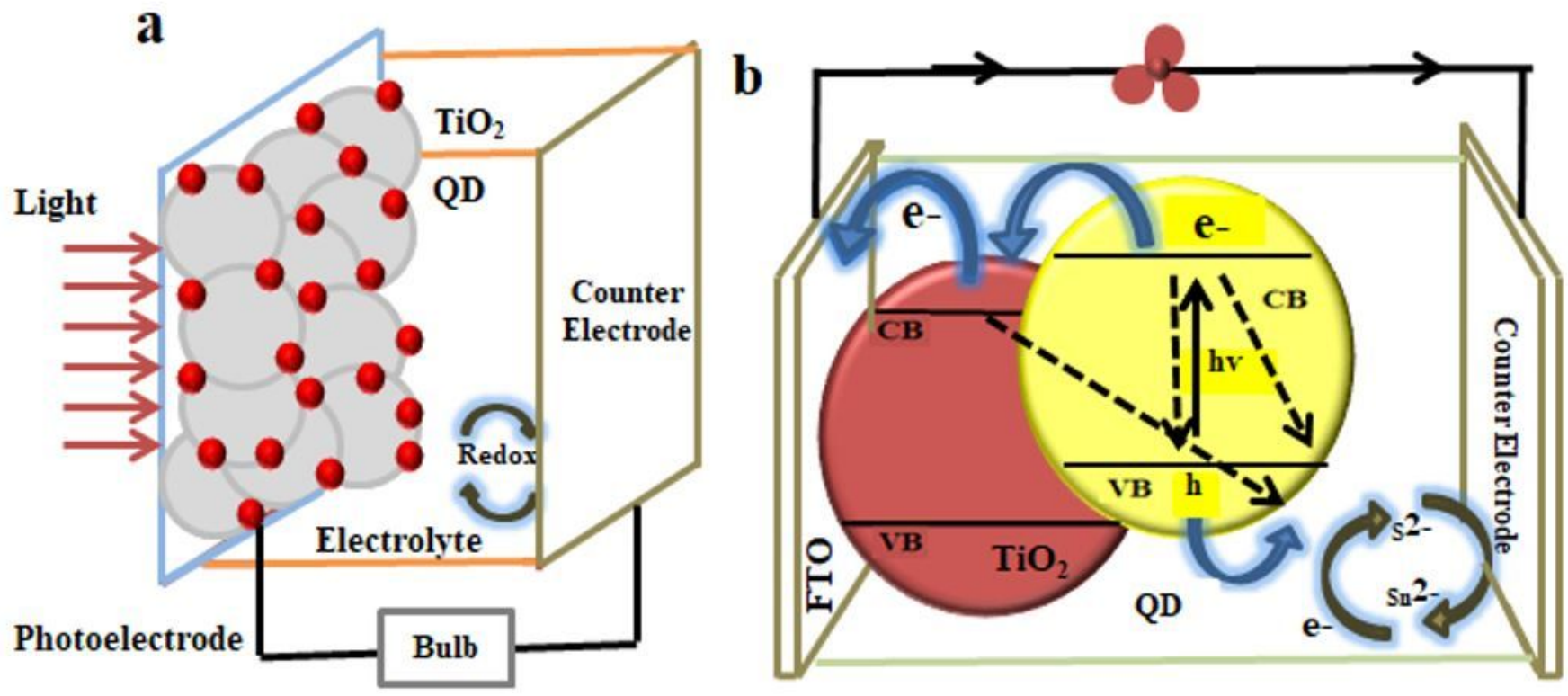

Figure 8

a Basic structure of a QDSC; and b Structure of photo induced charge transfer process.

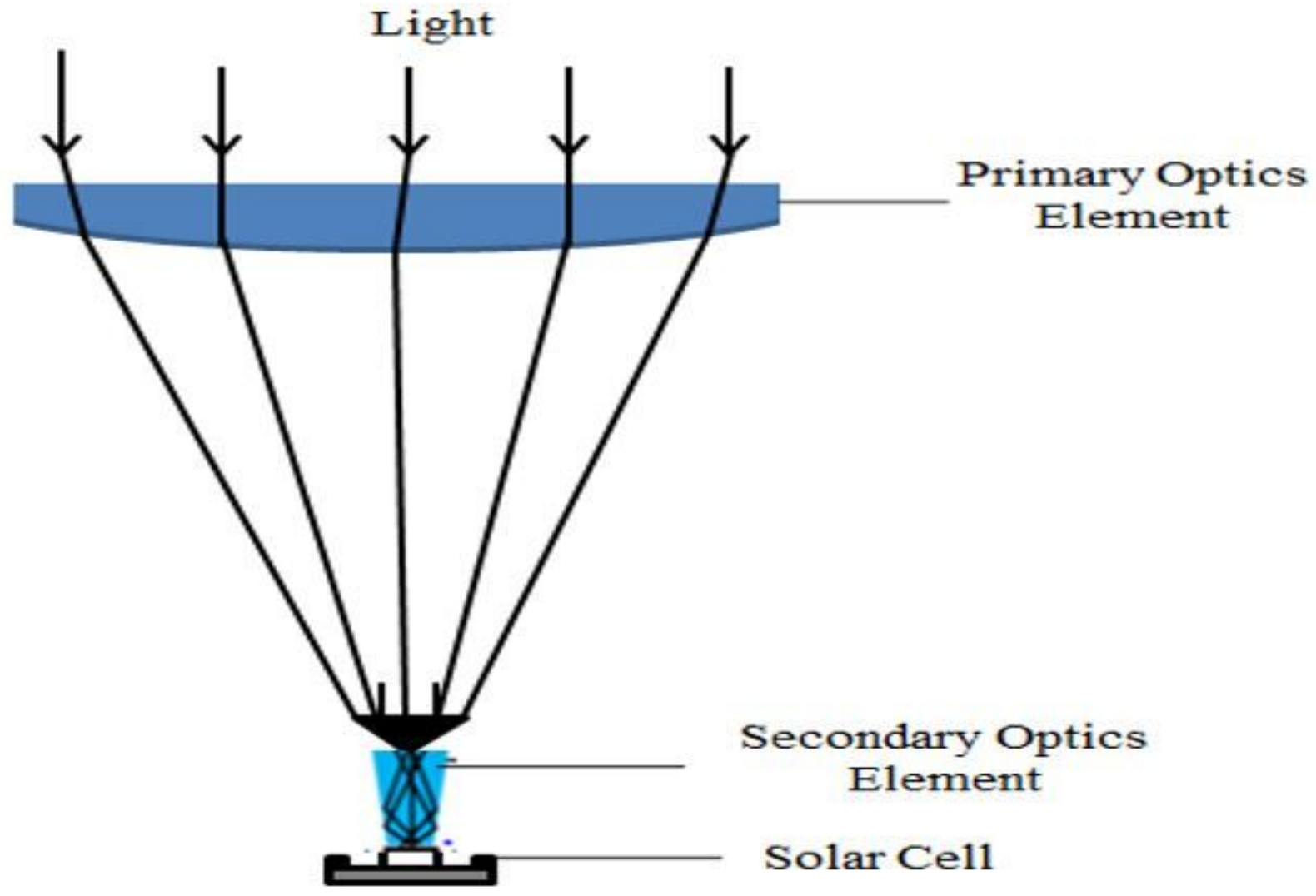

Figure 9

Structure of Concentrating photovoltaic cell. 


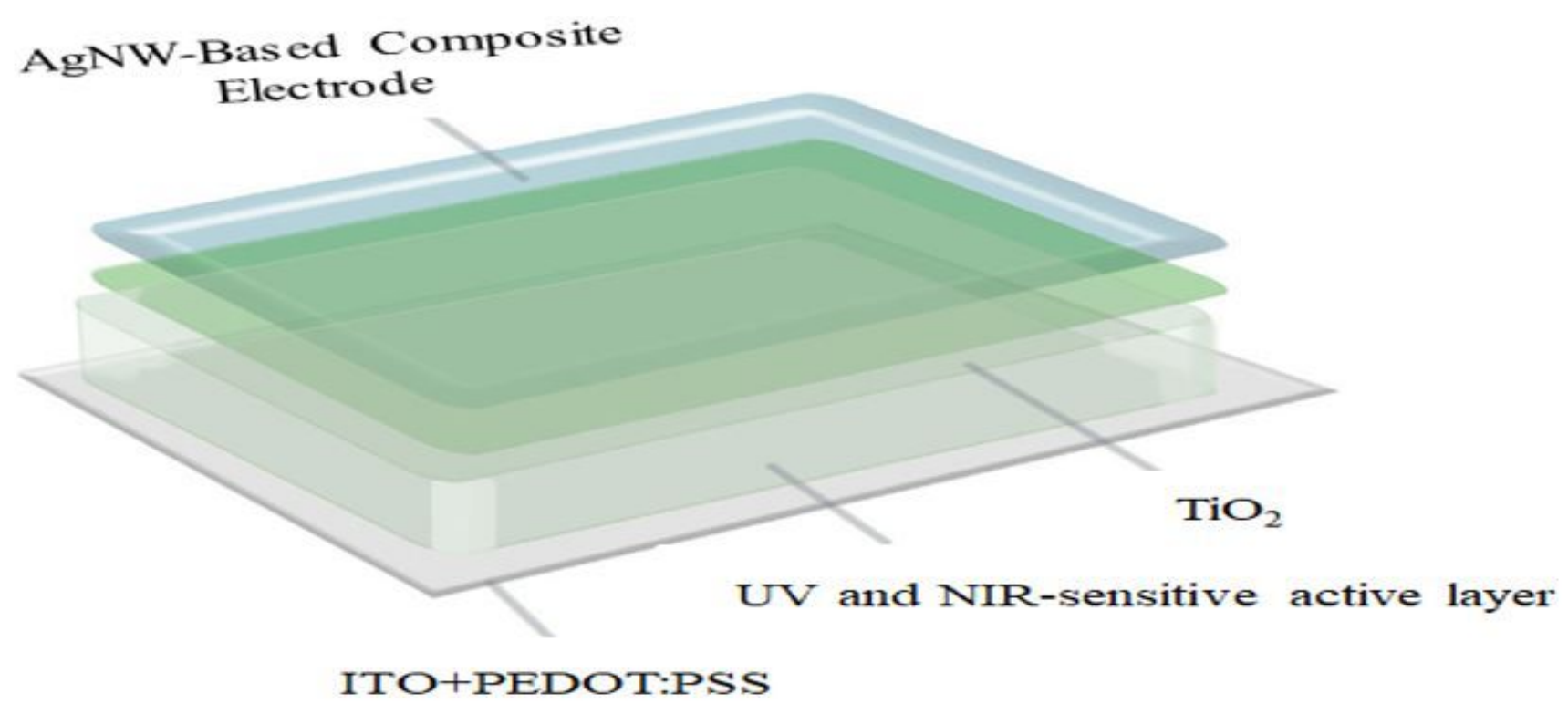

Figure 10

Schematic architecture of a visibly transparent cell [25]
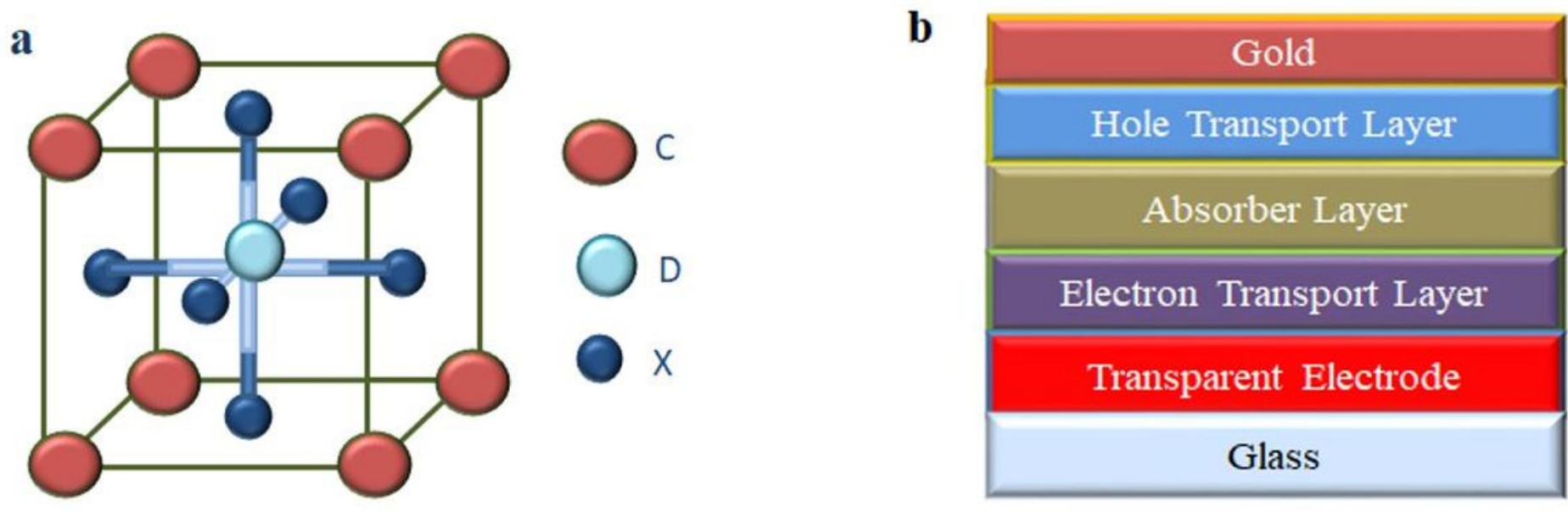

Figure 11

a Perovskite Crystal; \& b Schematic presentation of Perovskite solar cell. 